\title{
The Alberta Court of ApPEAl OPINES ON THE S.E.F. NO. 44 LIMITATION: THE STATUS QUO AND THE UNRESOLVED
}

\author{
GEOFFREY DUCKWORTH*
}

\section{INTRODUCTION}

The oft-criticized ambiguity of the Family Protection Endorsement S.E.F. No. $44^{1}$ has resulted in another Alberta Court of Appeal decision which holds that there are, essentially, two triggers regarding the "discoverability" limitation in clause 6(c) of the endorsement. In Shaver v. Co-operators General Insurance Co., ${ }^{2}$ Justice Côté opined in obiter that discoverability may occur when the injured plaintiff or her lawyer make a decision about the worth of the claims of the plaintiff (and, if applicable, of those of other persons injured in the accident), or that discoverability may occur later, once a judgment or binding settlement legally fixes the amounts of the claims. ${ }^{3}$ Under S.E.F. No. 44, the 12 -month limitation begins to run from the date in which "the eligible claimant or his legal representatives knew or ought to have known that the quantum of the claims with respect to an insured person exceeded the minimum limits for motor vehicle liability insurance in the jurisdiction in which the accident occurred."4

At trial, the parties agreed that discovery occurred well over nine years after the accident, when a partial judgment in favour of the plaintiff was consented to by the Motor Vehicle Accident Claims Fund and taken out. The subsequent action against the insurer was not commenced until over ten years after the accident. In this context, the Court of Appeal also pronounced that clause 6(c) of the endorsement will "quite often"5 let an injured plaintiff sue later than the ultimate ten-year deadline under section 3(1)(b) of the Limitations Act. ${ }^{6}$ The plaintiff was permitted to continue his claim against his insurer under S.E.F. No. 44.

The decision is not all bad news from an insurer's perspective. By leaving open the possibility that discoverability may occur prior to settlement or judgment, the Court of Appeal preserved the potential that some claims against insurers will be barred prior to settlement or judgment. At the same time, the consistency of the approach reduces uncertainty about when the limitation period begins to run, which minimizes the risk of precautionary claims against insurers.

Associate, Gowling Lafleur Henderson LLP, Calgary, Alberta.

Government of Alberta, "S.E.F. No. 44: Family Protection Endorsement," online: Alberta Treasury Board and Finance <http://www.finance.alberta.ca/publications/insurance/sef_44_endorsement.pdf> [S.E.F. No. 44].

2011 ABCA 367, 515 AR 345 [Shaver].

Ibid at para 18.

Supra note 1, cl 6(c). The full paragraph reads:

Every action or proceeding against the Insurer for recovery under this endorsement shall be commenced within 12 months from the date upon which the eligible claimant or his legal representatives knew or ought to have known that the quantum of the claims with respect to an insured person exceeded the minimum limits for motor vehicle liability insurance in the jurisdiction in which the accident occurred. No action which is commenced within 2 years of the date of the accident shall be barred by this provision.

Shaver, supra note 2 at para 43.

RSA 2000, c L-12. See Appendix A of this article. 
Unfortunately, the Court of Appeal declined to opine on whether the ten-year statutory limitation begins to run from the date of the accident or from the date of knowledge that the minimum limits have been exceeded. The Court of Queen's Bench had previously held that the ten-year limitation did not run from the accident, but from discoverability under the endorsement. $^{7}$

Brief comment shall be made following the culmination of this analysis regarding the potential impact of the new Insurance $A c t^{8}$ on S.E.F. No. 44.

\section{S.E.F. No. 44}

Under S.E.F. No. 44, a plaintiff can sue his or her own insurer in respect of an "inadequately insured motorist." 9 The amount payable under the endorsement is in excess of amounts a claimant would be entitled to recover from certain other sources, including an unsatisfied judgment fund. Pursuant to the Motor Vehicle Accident Claims Regulation, ${ }^{10}$ the Motor Vehicle Accident Claims Fund (the "Claims Fund") can pay up to a maximum of $\$ 200,000$, excluding costs, regarding all claims arising out of a single motor vehicle accident.

\section{FACTS}

The plaintiff, Lloyd Shaver, was injured on 14 July 2000 in a three-car collision with one other identified driver, Alison Jevne. Jevne and Shaver commenced separate personal injury actions, including actions against the Claims Fund. In August 2008 - prior to Shaver's trial on damages - Jevne advised that the Claims Fund had settled her claim for $\$ 100,000$, leaving only \$100,000 available for Shaver under the prescribed \$200,000 limit. In January 2010, the Fund advised it was prepared to enter into a partial judgment in favour of Shaver, in the amount of $\$ 100,000$, plus costs and disbursements. The partial judgment was entered on 19 January $2010 .^{11}$

Shaver's injury was a broken foot which transitioned into a pain syndrome in the foot, making it difficult for him to walk. His cardinal claim was loss of income available from an oilfield occupation he was no longer performing. Given his advancing injuries, Shaver commenced an action against his insurer on 29 July 2010, claiming coverage under S.E.F. No. 44. The insurer applied for summary judgment on the basis that the action was commenced beyond the ten-year "ultimate" limitation under section 3(1)(b) of the Limitations Act. ${ }^{12}$

\section{FINDINGS}

The insurer's summary judgment application was unsuccessful at both levels of court. At the Court of Appeal level, Justice Côté underscored the challenges incumbent in

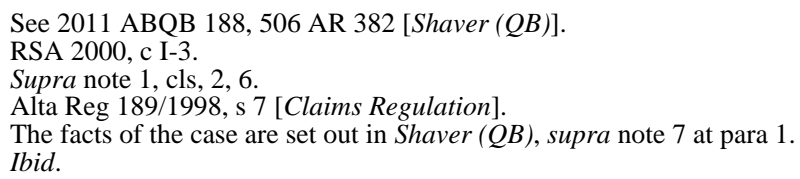


discoverability under the endorsement. The inquiry may be factually-intensive, contingent upon many factors, including medical conditions, which may evolve and progress over time. Discovery may require information, including about other parties, that the other parties may not be obligated to disclose. On these issues, the Court of Appeal opined as follows:

[Discoverability in this case] involves actions by and information from other entities, and indeed from other injured people.

If a plaintiff's own injuries are more than slight, it may take many months until his or her medical advisers can even tentatively assess the future, and before his or her counsel can suggest what those injury claims are worth. It is very common that the treating physician or surgeon initially hopes for a more or less full recovery; only the elapse of significant time shows that that is too optimistic in the case at hand.

\begin{abstract}
After seeking that clarity for one victim's injury claim, the same process must be followed with respect to all other claimants injured in the same accident. That may not be easy or quick. An injured person (or his or her solicitor) can ask his or her own medical advisers for such information. But he or she has no right to demand such information from other persons injured in the accident; and statutory or other confidentiality obligations may well prevent their advisers or agents from revealing that. If the two injured people owed each other no duty of care, or the other victim was plainly not negligent, or plainly did not cause the injuries, that other victim cannot be sued. So no discovery is available to compel such information.
\end{abstract}

Therefore it may well take a long time until one injured person can find whether the total claims from the accident exceed the compulsory minimum statutory liability insurance limits (or exceed any other relevant ceiling or sum). If a number of vehicles and passengers are involved, it could be a long time indeed.

It may well take over nine years to learn of inadequate insurance, or of the total claims exceeding minimum insurance limits, or both. It took that long here. ${ }^{13}$

\title{
V. PRIOR DECISIONS
}

Earlier decisions of the Alberta Court of Appeal identify other challenges that can arise in determining the running of the limitation. In particular, uncertainty about liability can make quantification of the "quantum of the claims" a speculative exercise. In the 1986 decision of Birtles v. Dominion of Canada General Insurance Co., ${ }^{14}$ the Alberta Court of Appeal dealt with the predecessor of the current endorsement. The Court posited that liability would have to be "convincing” to have a claim under the predecessor endorsement: 
[I]t is not a condition precedent that the insured person must in all cases obtain judgment against the wrongdoer before his right to claim against his own insurer arises under the Endorsement. His right to claim might arise earlier, but would require a convincing case of liability and want of any or adequate insurance coverage by the wrongdoer. ${ }^{15}$

In the 1993 Court of Queen's Bench decision of Shoemaker v. Wawanesa Mutual Insurance Co., ${ }^{16}$ Justice McMahon ruminated upon the ambiguity present in the phrase "knew or ought to have known that the quantum of the claims ... exceeded the minimum limits.” In particular, the Court grappled with determining who bore the obligation to calculate that the limits had been exceeded, noting that such a determination would turn on evolving liability and damages issues if not fixed by settlement or judgment. Counsel for the insurer argued that the plaintiff's counsel had an obligation to make a "reasonable and informed assessment of the minimal potential value of the damages." ${ }^{17}$ The failure to do so at the pertinent time meant that the plaintiff's action against the insurer was barred under S.E.F. No. 44.

Shoemaker involved a two car rear-end collision. The plaintiff commenced an action on 8 August 1988 for \$100,000 in general damages, plus undetermined special damages including lost wages and costs. The claim was amended on 26 September 1988, to the sum of $\$ 500,000$, including future loss of earnings, at the plaintiff's insistence. The plaintiff discharged her prior counsel and retained a new lawyer, who then commenced an action for coverage under the endorsement on 23 August 1991. In January 1993, the plaintiff obtained a judgment in the amount of $\$ 589,134.84$, plus taxable costs. Given the defendant's coverage limits of $\$ 300,000$, the deficiency was $\$ 289,134.84$. The insurer argued that the plaintiff's prior lawyer knew or ought to have known on 22 August 1990 that the minimum limits had been exceeded. ${ }^{18}$

Justice McMahon found that the limitation in S.E.F. No. 44 was ambiguous. He queried as to whether the "claims" could be the number claimed in the prayer for relief. He noted that this number may bear no relationship with the amount eventually recovered. Both liability and damage issues would affect the quantum of the eventual recovery. Clearer wording would be required to determine that the limitation started to run "merely on the basis of a sum claimed in the prayer for relief without regard to liability issues or a reasoned assessment of damages." "19 The Court rejected the possibility that the assessment as to whether minimum limits had been exceeded would be based on a client's demands.

The Court then considered whether the relevant determination, regarding the claims being exceeded, should be the lawyer's as opposed to the court's. It was not suggested that the plaintiff knew more than her lawyer. Justice McMahon elucidated the challenges inherent in calculating when minimum limits are exceeded: 
[C]an it be said that they meant counsel's opinion of the claim at some point in time and not the court's opinion as determined by judgment? A case is built for trial brick by brick. In the course of building, many a brick will prove weak, unreliable or unavailable. There will be moments when counsel would not settle for less than full perfect compensation and then there will be moments when counsel would happily recommend whatever could be obtained. At which of these moments are we to take counsel's opinion and start the limitation period running under para. 6(c)? Once running can it be stopped because counsel discovers his or her ace is a deuce? ${ }^{20}$

Justice McMahon attempted to explore the issue through the lens of the plaintiff's original lawyer. Early in the process, liability favoured the plaintiff though there were some negatives. The plaintiff was not wearing a seatbelt. The defendant was charged but acquitted of careless driving, even though the plaintiff had given evidence. The plaintiff had been forced to stop suddenly because of a pedestrian crossing her path, and the defendant had pleaded inevitable accident. ${ }^{21}$

Regarding the extent of the plaintiff's injuries, the lawyer knew that his client had driven herself home after the accident and telephoned her family physician. The damage to her vehicle was not extensive. The plaintiff was not hospitalized. By the pertinent date, the plaintiff had seen 12 doctors, most of whom had issued reports offering a wide range of opinions about the plaintiff's injuries. ${ }^{22}$

Justice McMahon opined that it was clear that the plaintiff's original lawyer was skeptical of the credibility of the plaintiff's complaints. The claims did not appear to be supported by the objective evidence. The two most favourable opinions were largely based on what the plaintiff and her male companion had described to the two reporting physicians. In many respects, the case would stand or fall on the plaintiff's evidence alone. There were unfavourable medical reports. By March 1991, counsel had prepared a settlement brief claiming about $\$ 235,000$, plus a retraining allowance. Counsel would have recommended settlement at $\$ 100,000 .^{23}$

Justice McMahon held that "neither the Plaintiff nor her legal representative knew or ought to have known that the quantum of her claims exceeded the minimum limits on or before August 22, 1990.”24 It was in that context that Justice McMahon expressly declined to opine that the limitation under the endorsement could never begin to run before final judgment or settlement:

I need not and do not decide that in no case can the limitation in para. 6(c) begin to run before final judgment or settlement. There may be cases where there is no doubt. This is not one.

Ibid at para 26.

Ibid at para 9.

Ibid at para 11 .

Ibid at paras 14-15.

Ibid at para 28. 
Given the ambiguity, the interpretation most favourable to the insured is that the limitation runs from the final judgment or settlement. That in my view is in any event the proper interpretation of para. 6(c). ${ }^{25}$

Justice McMahon's decision was upheld by the Court of Appeal, though the Court of Appeal went further to clarify that the limitation could run based on something other than final judgment or settlement. ${ }^{26}$ For the Court of Appeal, Justice Kerans posited:

We are all of the view that the learned Queen's Bench judge was right, for the reasons he gave, to say that the term was ambiguous. He resolved the ambiguity by invocation of the "contra proferentem" rule. He said:

"Given the ambiguity, the interpretation most favourable to the insured is that the limitation runs from the final judgment or settlement.”

We might add "or some other final determination.,"27

The Court of Appeal in Shoemaker found that the type of factual inquiry advocated by the insurer, which required the plaintiff's counsel to make a "reasonable and informed assessment of the minimal potential value of the damages," was "sterile and unhelpful."28 However, the appeal did not require the Court to determine whether the plaintiff's interpretation of the S.E.F. No. 44 limitation was correct. The trial judge had found that a "reasonable and informed assessment at the critical time would not have led to the conclusion that the minimal potential value of the damages exceeded the insurable limits." ${ }^{29}$ The Court of Appeal added that the interpretation made by Justice McMahon was a “compelling one.”30

\section{THE STATUS QUO}

In my view, Shaver is consistent with the earlier authority that the limitation under S.E.F. No. 44 will run from final judgment or settlement "or some other final determination." The Court of Appeal recognized the difficulties that could be encountered in reaching an opinion about the "quantum of the claims" in the absence of settlement or a final judgment. This approach is cautious and sensible while still preserving the potential to find for an earlier start date in the appropriate factual setting. ${ }^{31}$ Such cases will likely be relatively sparse. It is one thing for a limitation to require knowledge of an injury attributable to a defendant which

\footnotetext{
Ibid at paras 28-29.

Shoemaker (CA), supra note 17 at para 3.

Ibid.

Ibid at paras 4-5.

Ibid at para 7.

Ibid at para 8 .

This cautious approach appears consistent with the Ontario Court of Appeal's past approach in respect of a substantively identical endorsement limitation (the wording is produced below in note 37). In Caruso v Guarantee Co of North America (1996), 31 OR (3d) 339 (CA), Justice Finlayson opined at 348:

I have some difficulty in understanding the significance of the alternate limitation periods in s. 17 of the O.E.F. 44... I find the language ambiguous. In these circumstances, I think it ill advised to embark upon an analysis of whether the significant event is the [solicitor's] determination of the quantum of damages. I will content myself with accepting the finding of the motions judge that it is difficult to conclude in this case that the appellant's solicitor knew that her injuries would exceed the minimum limit more than 12 months before the action against the respondent was commenced.
} 
warrants bringing a proceeding. It is quite another to require accurate calculation above the minimum limits without the benefit of a settlement or final judgment.

From an insurer's perspective, the consistent approach of the Alberta courts to discoverability under the endorsement has a further advantage: it reduces the possibility of a flood of S.E.F. No. 44 claims, filed out of caution given uncertainty over the start of the limitation period.

\title{
VII. LOOKING AHEAD
}

\section{A. DiscoverabiLity AND EXCEEDING MiNIMUM LiMITS}

One interesting feature of Shaver is the Court of Appeal's indication that discoverability of minimum limits may involve actions by and information from others. For the Court, Justice Côté posited that discoverability was not just a matter of assessing the minimum limits set by law:

\begin{abstract}
One might assume that the minimum liability insurance coverage is fixed by law, so that no uncertainty about discoverability can arise from that. In form, that is true, but in substance it is not. The endorsement defines the claim payable to the insured as being net of a number of possible payments, including an "unsatisfied judgment fund”.... That point is critical here. One could look at that as quantum of this plaintiff's claim, or as funds available to pay it. Either way, it involves actions by and information from other entities, and indeed from other injured people.
\end{abstract}

Here it is common ground that sometimes it may take a number of years for an injured insured to learn whether he or she needs to sue his or her own insurer, because the opponent's insurance or other funds are inadequate. Or to learn that the total of all claims is less than the statutory minimum liability insurance coverage. $^{32}$

With respect, this rationale appears to conflict with the express wording of the limitation. The endorsement speaks precisely of the "minimum limits for motor vehicle liability insurance in the jurisdiction in which the accident occurred." 33 The minimum limit prescribed by the Claims Regulation is $\$ 200,000$. $^{34}$ While as a practical matter defendants may or may not have greater insurance coverage, the endorsement expressly requires consideration of the minimum limits in the jurisdiction.

In contrast to Shaver, two recent Ontario Masters' decisions ${ }^{35}$ have gone so far as to hold that a plaintiff's knowledge of the limits of a defendant's policy is “irrelevant": 
It is irrelevant when the plaintiffs became aware that their claims would exceed the limits of the inadequately insured motorist's liability insurance policy; what is relevant is when they became aware or ought reasonably to have known that their claims would exceed the statutory minimum limits in Ontario. ${ }^{36}$

Ontario's endorsement limitation at the time of the decisions was and still is in substance identical to Alberta's. ${ }^{37}$ Like Alberta's, the Ontario endorsement requires that the claim payable to the insured be the net of a number of payments, including an "unsatisfied judgment fund.”38

Both approaches have merits and shortcomings from a policy perspective. On the one hand, the Ontario interpretation is simpler, as it involves only the statutory amount. It does not involve inquiries into the coverage limits of other parties. It can be calculated more quickly and at an earlier stage in the litigation. At least in theory, the limitation could run at an earlier date and plaintiffs would be encouraged to act on their rights in a timely way. On the other hand, Alberta courts might query the wisdom of requiring plaintiffs to sue their insurers without regard to actual insurance coverage. If actual coverage limits are truly irrelevant, the Ontario approach would appear to require commencement of an action against an insurer even if a defendant confirms substantially greater insurance coverage beforehand. In other words, while timely action by plaintiffs might be encouraged, much of it might be precautionary claims against insurers, claims that could languish in the court system while actual coverage is determined.

\section{B. The Application of the Limitations ACt}

The application of the Limitations Act in respect of S.E.F. No. 44 remains uncertain. ${ }^{39}$ In Shaver $(Q B)$, Justice Veit held that the ten-year limitation did not commence at the time of the accident, but rather when the insured knew or ought to have known that the tortfeasor's coverage would be inadequate to cover the insured's damages. ${ }^{40}$ At the Court of Appeal, Justice Côté expressly declined to make the same finding. Rather, he held that:

[T]he contractual cl 6(c) in the endorsement quite often will purport to let the injured person sue later than the ultimate "ten-year" statutory s 3(1)(b) of the Limitations Act will. Therefore s 7(1) of the Limitations Act expressly allows that. And its s 7(2) does not forbid it. Or its s 7(2) does not forbid it in these circumstances.

37 Government of Ontario,

"OPCF 44R: Family Protection Coverage," online: Financial Services Commission of Ontario < http://www.fsco.gov.on.ca/en/auto/forms/Documents/OAP-1-Application-andEndorsement-Forms/1076E.pdf> [OPCF 44R]. The Ontario limitation is set out in section 17 of OPCF 44R, which reads:

Every action or proceeding against the insurer for recovery under this change form shall be commenced within 12 months of the date that the eligible claimant or his or her representative knew or ought to have known that the quantum of claims with respect to an insured person exceeded the minimum limits for motor vehicle liability insurance in the jurisdiction in which the accident occurred, but this requirement is not a bar to an action which is commenced within 2 years of the date of the accident.

Ibid, s 7(d).

See Appendix A for ss 3, 7. Section 3 sets out the two- and ten-year limitation periods; section 7 deals with extensions and the prohibition on reductions of limitation periods.

Supra note 7 at para 11. 
All that renders academic whether the ultimate 10 -year back-up section can be said to start later than is commonly supposed. ${ }^{41}$

At trial, the insurer had argued that the ten-year limitation under section 3(1)(b) of the Limitations Act had commenced at the time of the accident, and further that discoverability was not part of the ten-year limitation under the Act. That argument may have missed the point. The drafting of the endorsement imports discoverability into the insurance contract, such that the limitation only begins to run once there is discovery that the minimum limits have been exceeded. Indeed, the Court of Appeal seems to have acknowledged this briefly in Shaver: "Maybe ordinary limitation periods do not require evaluating the claim; but this one expressly does." 42

The Court of Appeal's pronouncement that the endorsement will quite often extend the ten-year statutory limitation may have to be revisited in a case where the 12-month endorsement limitation is found to have expired over ten years after the accident date. In such a case, the insured will point to the two-year limitation under section 3(1)(a) of the Limitations Act in order to preserve his claim. The insurer will counter that, despite the Court of Appeal's closing comments in Shaver, the decision was based on a determination that discoverability under the endorsement occurred less than 12 months before the commencement of the claim. In a case where the 12-month endorsement limitation has expired, the insurer will argue that the statutory ten-year limitation applies as the period which "expires first" under the Act, since discoverability is not part of ten-year rule. The issue will no longer be academic at that point.

\section{The NeW InSURANCE ACT}

The new Insurance $A c t^{43}$ took effect on 1 July 2012 by Proclamation. ${ }^{44}$ In my view, it will not impact the calculation of the limitation period in S.E.F. No. 44.

\section{A. SECTION 593}

Section 586 of the new Act (section 640 of the old Act) sets out the persons who are covered in a contract that provides insurance against loss resulting from the bodily injury or death of an insured in an accident caused by an uninsured motorist. Section 593 provides that an action or proceeding against an insurer in respect of a contract referred to in section 586, inter alia, must be commenced "within the limitation period specified in the contract, but in no event may the limitation period be less than 2 years from the occurrence of the accident." Section 593's predecessor under the old Act, being section 647, provided that the limitation could not be less than one year after the happening of the accident.

\footnotetext{
$41 \quad$ Shaver, supra note 2 at paras 43-44. Section 7(1) of the Limitations Act expressly allows for limitations under the Act to be extended by agreement. Ibid at para 10 .

See Appendix B for ss 558, 586, 593. Appendix B contains all sections of the new Insurance Act referred to. Section 558(1) stipulates that: “An action or proceeding against an insurer under a contract must be commenced (a) in the case of loss or damage to the automobile, not later than 2 years after the occurrence of the loss or damage.” OC 325/2011, (2011) A Gaz I, 580.
} 
Under S.E.F. No. 44, an “inadequately insured motorist” includes uninsured motorists. ${ }^{45}$ Prior to the new Act, the limitation under S.E.F. No. 44 already provided that "[n]o action which is commenced within 2 years of the date of the accident shall be barred by this provision." ${ }^{46}$ Section 593 will not change the limitation applicable to claimants suing their insurers in respect of accidents caused by uninsured motorists.

\section{B. SECTION 558}

Section 558 of the new Act is a general limitation set out under Part 5, Subpart 2, which deals with automobile insurance. Under section 558(1)(b), an action or proceeding against an insurer under a contract must be commenced, "in the case of loss or damage to persons or property, not later than 2 years after the cause of action against the insurer arose.” In the context of S.E.F. No. 44, section 558 may apply to claims against "inadequately insured motorists" who are under-insured rather than uninsured.

It would seem that the 12 months for bringing an action under S.E.F. No. 44 is "not later" than two years after the cause of action arose. However, it might be argued that the "cause of action” under S.E.F. No. 44 arises independently of discoverability under the limitation. An insurer may argue at some point that the cause of action under S.E.F. No. 44 arises when the minimum limits have been exceeded and the obligation to indemnify arises, quite apart from discoverability of that excess.

While the argument might have some initial appeal, it is my view that it would not succeed. First, under clause 6(a)(i) of S.E.F. No. 44, an eligible claimant is required to provide the insurer with written notice of "any claim made on account of the accident" as one of the "conditions precedent to the liability of the Insurer to the eligible claimant." Absent such notice, there is no liability or cause of action against the insurer.

The cause of action under S.E.F. No. 44 is in breach of contract. The fact that an abstract calculation can be made ex post facto by a court would not necessarily mean that the insurer was in breach of its obligation under the endorsement at the pertinent time. At the time of a proceeding on the limitation, the court would have access to information that the insurer and the eligible claimant may not have had at the pertinent time. In my view, there can be no cause of action under section 558 where neither party to the insurance contract is aware of the existence of a claim. Otherwise, in the context of S.E.F. No. 44, section 558 of the Insurance Act would effectively function as an absolute limitation, like the ten-year rule under paragraph 3(1)(b) of the Limitations Act — only eight years shorter!

The ambiguity of S.E.F. No. 44 would significantly complicate the matter of calculating the date upon which a cause of action arises under the endorsement if discoverability is not relevant. The potential scenarios are unlimited. The date might be the time in which another eligible claimant reaches a partial judgment with the Claims Fund. It could be a date in which the eligible claimant experiences a transition from a seemingly transient injury to a chronic pain condition. Such a date might be a date a claimant experiences very significant pain for 
the first time or on a date preceded by numerous continuous dates of chronic pain. Would a formal diagnosis or a written diagnosis be required? Would one diagnosis be sufficient, or would multiple opinions be necessary? Would conflicting results or improved medical conditions restart the clock? Again, if discoverability is not relevant to when the cause of action arises under S.E.F. No. 44, the dates in which any of this information would be communicated - if the information was communicated at all — would not matter. Under that interpretation, the cause of action would arise when the quantum of the claims exceeded the minimum limits.

Other claims, including loss of income, could further complicate the calculation. If an eligible claimant attends at work for a substantial period of time, even while the medical condition seems dismal, would the quantum of claims exceed the minimum limits? At what point? Would the cause of action arise on the date of a poor performance evaluation? The date a certain task could not be completed? The date the claimant no longer considered herself fit for the job? During a leave of absence? At what part of the leave of absence?

Given that numerous eligible claimants might be involved in the calculation, and the claim of each would have bearing on when the quantum of claims had exceeded the minimum limits, the potential for extremely complicated fact situations is infinite. In short, if a cause of action arises in respect of S.E.F. No. 44 under section 558 in the absence of discoverability, trying to determine the date would become an arbitrary and purely conjectural process. The lack of communication between the parties at the pertinent times could complicate the court's subsequent role in making the calculation and heighten uncertainty as to the eventual outcome.

From a fairness point of view, the absence of discoverability in calculating the cause of action date would mean no requirement that the insured knew or even ought to have known of the information going into the calculation. An eligible claimant's cause of action could expire without his ever having had the necessary information. Against this ambiguity, there would be every reason for a court to apply the rule of contra proferentem and interpret the date in which a cause of action arises under the endorsement in a manner favourable to the insured.

Finally, a finding that a cause of action can arise independently of, and earlier than, discoverability under S.E.F. No. 44 could create a conflict with section 7(2) of the Limitations Act. That section stipulates that an agreement that purports to provide for a reduction of a limitation period provided by the Limitations Act is not valid. Pursuant to section 558(2) of the new Insurance Act, all automobile insurance policies must now include the following statement: "Every action or proceeding against an insurer for the recovery of insurance money payable under the contract is absolutely barred unless commenced within the time frame set out in the Insurance Act."

While this particular contractual provision would be supported by the Insurance Act, interpreting “cause of action” under S.E.F. No. 44 as arising independently of discoverability would mean that the cause of action of the insured would expire before the two-year limitation under the Limitations Act, contrary to section 7(2). 
For all of these reasons, it is my view that courts will not interpret section 558 of the new Insurance Act as shortening the limitation provided under S.E.F. No. 44.

\section{APPENDix A}

Limitations Act, RSA 2000, c. L-12 (current)

\section{Limitation periods}

3(1) Subject to section 11, if a claimant does not seek a remedial order within

(a) 2 years after the date on which the claimant first knew, or in the circumstances ought to have known,

(i) that the injury for which the claimant seeks a remedial order had occurred,

(ii) that the injury was attributable to conduct of the defendant, and

(iii) that the injury, assuming liability on the part of the defendant, warrants bringing a proceeding,

or

(b) 10 years after the claim arose,

whichever period expires first, the defendant, on pleading this Act as a defence, is entitled to immunity from liability in respect of the claim.

RSA 2000 c L-12 s 3; 2007 c 22 s 1

\section{Agreement}

7(1) Subject to section 9, if an agreement expressly provides for the extension of a limitation period provided by this Act, the limitation period is altered in accordance with the agreement.

(2) An agreement that purports to provide for the reduction of a limitation period provided by this Act is not valid. 


\section{APPENDIX B}

Insurance Act, RSA 2000, c I-3 (effective 1 July 2012)

\section{Limitation of actions}

558(1) An action or proceeding against an insurer under a contract must be commenced

(a) in the case of loss of or damage to the automobile, not later than 2 years after the occurrence of the loss or damage, and

(b) in the case of loss or damage to persons or property, not later than 2 years after the cause of action against the insurer arose.

(2) A policy to which this Subpart applies must contain the following statement:

Every action or proceeding against an insurer for the recovery of insurance money payable under the contract is absolutely barred unless commenced within the time set out in the Insurance Act.

2008 c 19 s 29

\section{Limited Accident Insurances}

\section{Uninsured motorist}

586(1) If an insurer provides in a contract insurance against loss resulting from bodily injury to or the death of a person insured arising out of an accident when

(a) there is legal liability of another person for the injury or death, and

(b) the other person has no insurance against the liability for the injury or death or cannot be identified,

that insurance applies only in respect of

(c) a person who sustains bodily injury or death while driving, being carried in or on, entering, getting on or alighting from the described automobile in respect of which insurance against liability arising out of bodily injury to or the death of a person caused by an automobile or the use or operation of an automobile is provided under the contract, and

(d) the insured named in the contract and the spouse or adult interdependent partner of the insured named in the contract and any dependent relative residing in the same 
dwelling place as the insured named in the contract who sustains bodily injury or death while driving, being carried in or on, entering, getting on or alighting from, or as a result of being struck by, any other automobile that is defined in the contract for the purposes of that insurance.

(2) The insurance mentioned in subsection (1) does not apply in respect of a person specified in the contract who has a right of recovery under the Motor Vehicle Accident Claims Act or similar legislation of any other province or territory or of any state or the District of Columbia of the United States of America.

2008 с 19 s 29

\section{Limitation re commencement of action}

593 An action or proceeding against an insurer in respect of insurance under a contract referred to in section 586, 587 or 588 must be commenced within the limitation period specified in the contract, but in no event may the limitation period be less than 2 years from the occurrence of the accident. 